International Journal of Engineering \& Technology, $7(2.13)(2018) 425-428$
SPC
International Journal of Engineering \& Technology
Website: $w$ ww.sciencepubco.com/index.php/IJET
Research Paper

\title{
E-Commerce Website as Seller Media for End User at Banyuwangi Mall
}

\author{
Pending Puji Dwi Astuti*, A.A. Gde Satia Utama \\ Universitas Airlangga, Surabaya, Indonesia \\ *Corresponding author E-mail: pending.puji.dwi-2014@feb.unair.ac.id
}

\begin{abstract}
This study aims to perform evaluation using End User Computing Satisfaction theory on Seller Account Banyuwangi Mall. The approach used in this research is qualitative explorative approach with case study method from SME seller of goods product. The data collection procedure used in this research is interview, observation, and documentation. The result of this research based on evaluation of Banyuwangi Mall e-commerce system shows have satisfaction as end user. The current system is adequate, but needs to be improved. Such improvements are used to improve the efficient use of the Banyuwangi Mall ecommerce system, especially the seller account system operated by SME actors who sell their products through Banyuwangi Mall. The improvement is a redesign of the sales system. The designs made have been adjusted based on the necessary improvements taking into consideration the costs and benefits, as well as the internal controls in each of their activities, so that the design proposal on the Banyuwangi Mall seller account is well worth considering. Further research is expected to be an evaluation and improvement of the appearance of the customer or buyer to make buyers more interested in transactions through Banyuwangi Mall and simplify the use.
\end{abstract}

Keywords: EUCS, Seller Account, Banyuwangi Mall, SME

\section{Introduction}

Banyuwangi has a rapidly growing number of SME. Based on data contained in the statistic central department in 2015, the number of SME in Banyuwangi reached 269.267 actors [1] Banyuwangi became the main pioneer that provides facilities for sale of its SME products through integrated digital marketplace platform. The name of it is Banyuwangi Mall [2]. In 2017, based on data obtained from the administrative site Banyuwangi Mall indicates that the number of SMEs that have been registered has reached 96 sub-districts from various districts in Banyuwangi. While the number of experienced products contain as many as 591 products. In addition to 96 SMEs there are still 30 SMEs are still on the waiting list. SMEs who are on the list that can not be registered to Banyuwangi Mall because there are still some requirements that are still not met com-pletely. But in the digital market this place still has problems. One of them is the number of SMEs registered now can not be done by buyers Banyuwangi Mall. SME owners of products that are marketed on product details, but complete address and contacts cannot be contacted. Only users can see the SME name of the product owner only.

Based on the preliminary survey that has been done, the reason that neglected to contact people is because not all SME owners understand the performance of Banyuwangi Mall. We would like to contact directly to the admin of Banyuwangi Mall and ask the contact person from the owner of SME to discuss. Another disadvantage of the current system is that there is no number or number of web visitors who have seen one product being sold, Sellers do product updates only by admin using the admin Banyuwangi Mall, while the Banyuwangi Mall can do every day every product listed.
Therefore, redesigning e-commerce system in seller account Banyuwangi Mall is very necessary.

E-commerce or electronic commerce is part of electronic business that performs transactions of buying and selling of goods and services through internet media[3], [4]. These transactions include advertising, marketing, customer support, security, delivery, and payment (Laudon and Laudon, 2016: 87) [5]. This is supported by Turban, et al. (2018: 7) which explains that e-commerce is a process of transactions ranging from purchasing, selling, transfer, exchange of products in the form of goods, services, or information made through computer media, whether through internet or intranet [6].

In this study, e-commerce is included into the type of Consumer to Consumer (C2C). The first consumer party is the owner of SMEs and other consumers are buyers who want products produced by SMEs. So this research will focus on e-commerce type C2C [7].

End User Computing Satisfaction was first proposed by Doll and Torkzadeh in 1988. The instrument is designed for general purpose and can be tested in a variety of settings, times, and people. This instrument will be provided to discrete computer simulation users and used to test psychometric stability [8]. Doll and Torkzadeh provide evidence that End User Computing Satisfaction (EUCS) greatly maintains its psychometric properties when applied to discrete computer simulation users, so EUCS is urgently needed to test the implementation of a technology (McHaney and Cronan, 2002) . Doll and Torkzadeh (1988) raised the construction of ease of use (easy to use). In addition, there are four other constructions contained in EUCS, namely content, accuracy, format, and timeliness (Doll and Torkzadeh, 1988) [8].

Bodnar and Hopwood (2013: 1) explain that the accounting information system is a collection of resources, be it equipment and human designed to convert financial data and other data into an 
information. Accounting information system transforms data into an information either manually or through a computerized system in processing input into output. There are two SIAs associated with this research, namely SIA Sales and SIA Cash Receipts [9].

Cost and benefit analysis is a model in economics commonly used by various organizations to choose various investment alternatives available and for investment decision making (Ali 2012) [10]. The existence of cost and benefit analysis will help determine the feasibility or lack of a system to develop (Ali, 2012; Allen, 2007; Berghout, et al., 2011) [11]. If the expected benefit is greater than the resources issued, then the information system is considered to have value and feasible to be implemented.

Various studies on system evaluation of online shopping sites have been done. Al-Qeisi, et al., (2014) has conducted research on the quality of website design and user behavior. In this study used the Unified Theory of Acceptance and Use of Technology (UTAUT) model [12]. Research conducted by Azis and Kamal (2016) using the Unified Theory of Acceptance and Use of Technology 2 model (UTAUT2) explains that there is influence of consumer behavior towards the desire to buy SME products in West Java . Another study was conducted in China by Li, et al., (2017) which explains that security, social motivation and playfulness factors influence consumer behavior in e-auction transactions that are a type of $\mathrm{C} 2 \mathrm{C}$ e-commerce. The test uses the Technology Acceptance Model (TAM) model [13]. While the evaluation system that will be used by researchers using End User Computing Satisfaction.

Past researchers focused only on evaluating the system. In this study, researchers will provide a system design to complement the existing system. So that the design of the new system will provide more benefits for users, namely Seller (SME) and Buyer.

\section{Methodology}

The approach used in this research is qualitative explorative approach with case study method. This qualitative method is used to investigate the various problems, circumstances, and soc ial phenomena of society in everyday life (Yin, 2016: 3). While the explorative approach explains that the research relates directly to the object of research (Creswell, 2014: 16) [14]. Objects in this research is e-commerce system seller account Banyuwangi Mall. Yin (2016: 4-5) also explained that case study method is a strategy used to answer various research questions related to how that is in the formulation of the problem, researchers can not organize, control, and influence the object of research, and focus on events contemporary.

This study focuses more on the sales system of SMEs listed in Banyuwangi Mall. The perpetrators of SMEs selected are SMEs with goods products. This is because most orders are goods. The system is evaluated based on its users, SMEs.

The type of data used in the study is qualitative data, data expressed in the form of words, sentences, and can be presented in the form of images. Sources of data used in this study are primary data and secondary data. The data collection procedure used in this research is interview, observation, and documentation. The research location are Rumah Kreatif (letter will be address as Creative House) Banyuwangi as manager in Banyuwangi Mall, Department of Cooperative and Micro Enterprise, and SMEs Location.

\section{Results and Discussion}

Banyuwangi Mall is one of the marketplaces or online stores of all SME products in Banyuwangi formed by the Government of Banyuwangi Regency in collaboration with BNI'46 (Persero) Jakarta. The address of this online shopping website is www.banyuwangi-mall.com.

The cooperation between Banyuwangi Regency and Bank BNI'46 is one of the embodiment of CSR Bank BNI'46. Therefore, all e- commerce related transactions from products of SME actors are done through BNI channels. These methods include BNI SMS Payment, BNI Virtual Account Payment, BNI Credit Card, and BNI Debit Online.

The difference between online shopping sites Banyuwangi Mall with other online shopping sites (private property) is in terms of product prices displayed on the website. Online shopping sites generally cost more than the original seller (the product owner). In accordance with economic principles, it is because the distributor wants to get the maximum profit by issuing the smallest capital. But at Banyuwangi Mall all products are sold at normal prices, where that determines the price of products installed on the website is the seller (SME). So that the perpetrators of SMEs will benefit according to their wishes. While the managers of Banyuwangi Mall only as an intermediary and do not take their own profit from the sale of products made through Banyuwangi Mall. Creative House is a place entrusted by the Government of Banyuwangi Regency under the line of the organization Department of Cooperatives and Micro Enterprises to form a digital economic ecosystem through coaching for the perpetrators of SMEs in Banyuwangi to improve capacities and capabilities of SMEs.

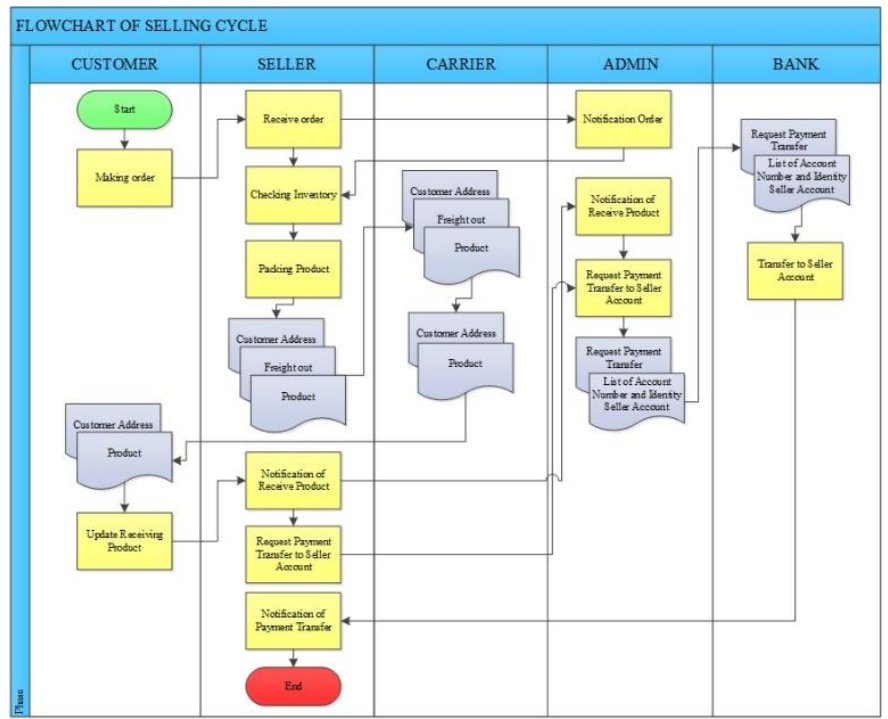

Fig 1. Business Process in Banyuwangi Mall

Figure above explains that in the business process Banyuwangi Mall is an online store that is included in e-commerce customer to customer $(\mathrm{C} 2 \mathrm{C})$. This is because Banyuwangi Mall is only a third party that plays a role to provide online platform. While the sales transaction is done by one consumer to another consumer. This consumer is the perpetrators of SMEs who sell their products through Banyuwangi Mall and other consumers are buyers who are interested in products sold through Banyuwangi Mall.

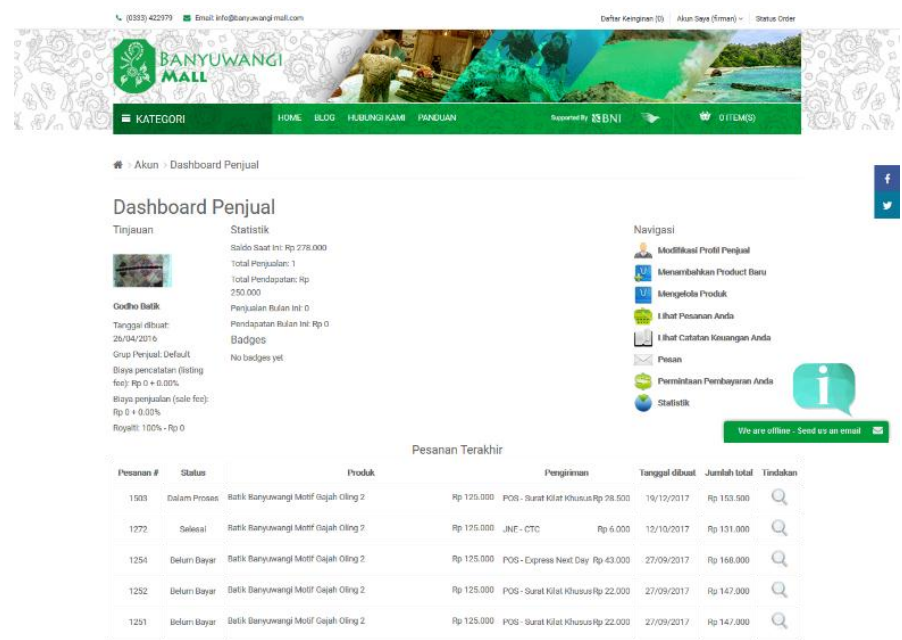

Fig 2. Seller Account in Banyuwangi Mall 
The figure above is taken from the official account of one of the sellers in Banyuwangi Mall on behalf of Sekar Kedaton. All of these menus can be edited by the seller themselves. So the data changes do not need to wait from the admin Banyuwangi Mall. View above is used to perform evaluation using End User Computing Satisfaction method.

Table 1. End User Computing Satisfaction

\begin{tabular}{|c|c|c|}
\hline No. & Construction & Result \\
\hline 1. & Content & $\begin{array}{l}\text { Content is good and quite helpful. Because } \\
\text { most of the informants feel satisfied, then } \\
\text { from the side of the content in the seller } \\
\text { account gives satisfaction to perpetrators of } \\
\text { SMEs. }\end{array}$ \\
\hline 2. & Accuracy & $\begin{array}{l}\text { The data presented in the system is accurate } \\
\text { and can be believable. So that can be said if in } \\
\text { terms of accuracy provide satisfaction to user. }\end{array}$ \\
\hline 3. & Format & $\begin{array}{l}\text { All users feel satisfied and say if the form of } \\
\text { display in Banyuwangi Mall is good and neat. } \\
\text { So they feels very useful and helps in viewing } \\
\text { financial records that have been presented. }\end{array}$ \\
\hline 4. & Easy of use & $\begin{array}{l}\text { All users are satisfied because in learning this } \\
\text { system does not require a long time. }\end{array}$ \\
\hline 5. & Timeliness & $\begin{array}{l}\text { All users feel satisfied because all the process } \\
\text { of presenting data and information runs } \\
\text { quickly. }\end{array}$ \\
\hline
\end{tabular}

The results of the evaluation that has been done used as the basis in making the design proposal in the seller account Banyuwangi Mall.

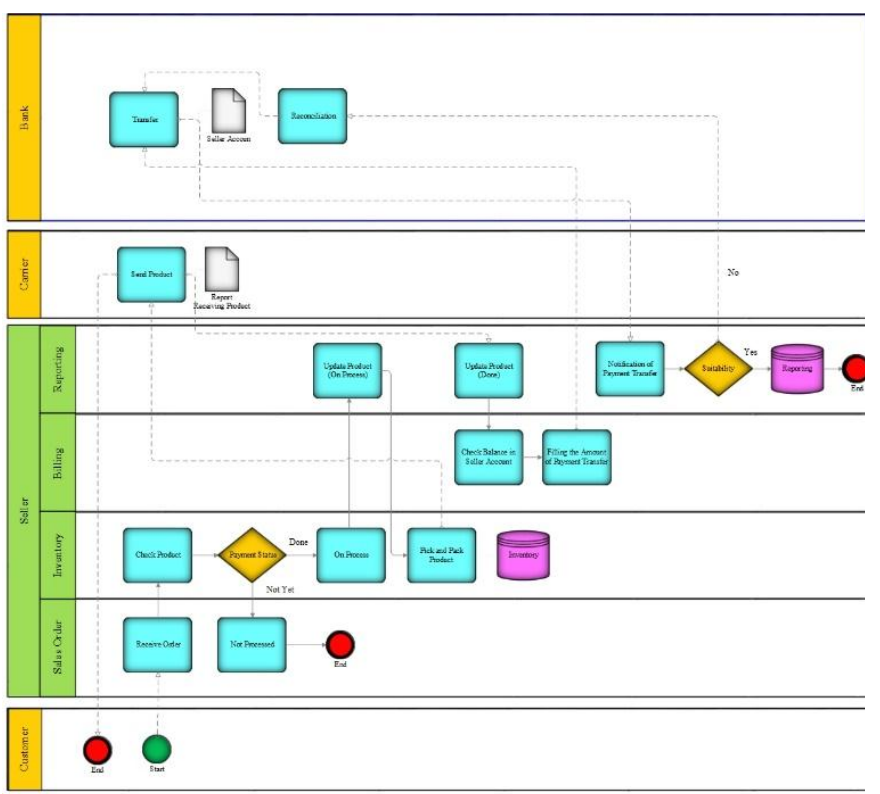

Fig 3. Bussiness Process Suggestion

Based on Business Process above shows the following activities.

1. The seller receives customer order notification.

2. Products ordered by customers in check availability.

3. Products that have been checked availability then checked the status of payment in the seller's account.

4. When payment has not been made, the order will not be processed. But when the customer has made the payment, then the packaging of products that have been ordered and automatically reduce inventory in the website display.

5. The product that has been packaged and then sent to the customer through the delivery service by providing the cost of the sender himself who will be replaced by the Bank.

6. When the goods have been sent, then the seller will get the product report sent.

7. The seller updates the items sent on the system as a basis for making payment requests to the Bank.

8. The proof of the item will be processed by the Bank and then transfer the payment money in accordance with the selling price and substitute the shipping cost to the account of each seller.

9. Transfer the money will directly enter the system and reduce the amount of balance listed in the system Banyuwangi Mall and sales activities finished shining.

Costs required are training for SME players or representatives who participate in assisting their business with the use of updated systems. The train-ing is held weekly with different participants for three months in a row. But every week is done with participants of different SME. So, out of 92 MSEs divided into four groups (a month $=4$ weeks). Up to each group there are 23 perpetrators of SMEs.

The benefits of the development of the system is the Creative Rumak no longer need an additional employee. Salaries that should be used to pay new employees can be allocated to training or other needs.

$$
\text { Payback period }=\frac{12.000 .000}{18.000 .000} \times 12 \text { months }=8
$$

The total training cost of the latest system can be fulfilled in the 8 th month of salary when accepting a new employee.

\section{Conclusion}

The result of this research based on evaluation of Seller Account on Banyuwangi Mall e-commerce system shows have satisfaction as end user. The current system is adequate, but needs to be improved. Such improvements are used to improve the efficient use of the Banyuwangi Mall ecommerce system, especially the seller account system operated by SME actors who sell their products through Banyuwangi Mall. The improvement is a redesign of the sales system. The designs made have been adjusted based on the necessary improvements taking into consideration the costs and benefits, as well as the internal controls in each of their activities, so that the design proposal on the Banyuwangi Mall seller account is well worth considering. Further research is expected to be an evaluation and improvement of the appearance of the customer or buyer to make buyers more interested in transactions through Banyuwangi Mall and simplify the use.

\section{References}

[1] banyuwangikab.go.id, "Banyuwangi Proteksi UMKM yang Tumbuh Pesat.”

[2] banyuwangikab.go.id, "Genjot Pemasaran UMKM, Banyuwangi Luncurkan Digital Market Place.”.

[3] A. S. Ahmar, R. Hidayat, D. Napitupulu, R. Rahim, Y. Sonatha, and M. Azmi, "eConf: an Information System to Manage the Conference," J. Phys Conf. Ser, vol. 1028, no. 1, p. 012044, Jun. 2018

[4] D. Napitupulu, M. Syafrullah, R. Rahim, D. Abdullah, and M. Setiawan, "Analysis of user readiness toward ICT usage at small medium enterprise in south tangerang," J. Phys. Conf. Ser., vol. 1007, no. 1, p. 012042 , Apr. 2018.

[5] K. C. Laudon and J. P. Laudon, Information Systems, Organizations, and Strategy. 2016.

[6] E. Turban, J. Outland, D. King, J. K. Lee, T.-P. Liang, and D. C. Turban, Electronic Commerce 2018. 2018.

[7] M. Pradana, "Klasifikasi Bisnis E-Commerce Di Indonesia," Modus, vol. 2727, no. 22, pp. 163-174, 2015

[8] T. M. Somers, K. Nelson, and J. Karimi, "Confirmatory Factor Analysis of the End-User Computing Satisfaction Instrument: Replication within an ERP Domain," Decis. Sci., vol. 34, no. 3, pp. 595-621, 2003.

[9] G. H. Bodnar and W. S. Hopwood, Accounting Information Systems.

[10] A. Ali, "A Framework for Using Cost-Benefit Analysis in Making the Case for Software Upgrade," Issues Informing Sci. Inf. Technol., vol. 9, pp. 399-409, 2012.

[11] E. Berghout, M. Nijland, and P. Powell, "Management of lifecycle costs and benefits: Lessons from information systems practice," Comput. Ind., vol. 62, no. 7, pp. 755-764, 2011. 
[12] K. Al-Qeisi, C. Dennis, E. Alamanos, and C. Jayawardhena, "Website design quality and usage behavior: Unified theory of acceptance and use of technology," J. Bus. Res., vol. 67, no. 11, pp. 2282-2290, 2014

[13] R. Li, T. L. (Doreen) Chung, and A. M. Fiore, "Factors affecting current users' attitude towards e-auctions in China: An extended TAM study," J. Retail. Consum. Serv., vol. 34, no. January 2016, pp. 19-29, 2017.

[14] J. W. Cresswell, "Research Design. Qualitative, Quantitative and Mixed methods approaches," Research design Qualitative quantitative and mixed methods approaches. p. 398, 2014. 